Running head: APPLYING A TALENT MANAGEMENT LENS

De Vos, A., Dries, N. (2013). Applying a talent management lens to career
management: The role of human capital composition and continuity.
International Journal of Human Resource Management, 24 (9), 1816-1831. Ans De Vos

Antwerp Management School, Antwerp, Belgium

Nicky Dries

Faculty of Business and Economics, KU Leuven, Leuven, Belgium

Ans De Vos, Antwerp Management School, Sint Jacobsmarkt 9-13, 2000 Antwerpen, Belgium. Phone +32 265 4147. E-mail ans.devos@ams.ac.be

Ans De Vos is full professor at Antwerp Management School, where she holds the SD Worx chair "Next generation work: Creating sustainable careers". As part of this chair, she conducts research on changing psychological contracts, career expectations of different generations, and pathways to sustainable career management. She is also research fellow at the Faculty of Economics and Business Administration, KU Leuven and co-promoter of the Policy Research Centre on Work and Social Economy. Her work has been published in international peer-reviewed journals including Journal of Organizational Behavior, Journal of Vocational Behavior, Journal of Occupational and Organizational Psychology, and European Journal of Work and Organizational Psychology.

Nicky Dries is a postdoctoral researcher at the KU Leuven, Faculty of Business and Economics (Belgium). Her primary research interests are talent management and career management - more specifically, the interplay of organizational-strategic and individualpsychological factors in shaping careers. Nicky has published articles in international journals 
in the areas of career management, human resource management, and vocational psychology, and is in the editorial board of Journal of Vocational Psychology (JVB), European Journal of Work and Organizational Psychology (EJWOP), and Global Journal of Psychology Research (GJPR). Currently, she is the supervisor of three $\mathrm{PhD}$ projects on talent management, as well as a co-supervisor of the Policy Research Centre Work and Social Economy. In addition, she is actively involved in two large-scale cross-cultural projects on contemporary careers, i.e. 5C (Consortium for the Cross-Cultural Study of Contemporary Careers) and the Career Adaptability/Life Design project. 


\begin{abstract}
The aim of the current study is to gain empirical insight into how organizations' human capital composition (both in terms of uniqueness and strategic value) affects the way they design and implement their career management policies. We draw from conflicting assumptions found in the careers literature and the talent management literature to develop our hypotheses. Organizational-level surveys administered to the HR directors of 306 companies located in Belgium provided the data for the study. Our basic assumption - in stark contrast to prevailing assumptions in the careers literature - was that the more importance organizations attach to continuity in light of their human capital composition, the more they will adhere to 'traditional' models of career management (i.e. strategic, paternalistic, bounded, and formalized). Our study yielded mixed findings. Both threats of qualitative (value) and quantitative (uniqueness) human capital shortages were found to be important determinants of importance attached to continuity as a career management goal and consequently, of an organization's approach to career management. We argue that the careers literature might take lessons from the talent management literature by acknowledging the fact that careers serve strategic functions for organizations, whereas the talent management literature might build on insights from the careers literature on the mechanisms by which to retain and engage individual career actors.
\end{abstract}

Keywords. talent management, human capital, career management, boundaryless careers, protean careers 


\section{Applying a Talent Management Lens to Career Management: The Role of Human}

\section{Capital Composition and Continuity}

Despite over a decade of debate and hype about talent management as a crucial human capital challenge (Michaels, Handfield-Jones, \& Axelrod, 2001) there has been strikingly little empirical research (Boudreau \& Ramstad, 2006; Collings \& Mellahi, 2009). Publications often depart from a distinctly normative stance - typically listing a set of best practices prescribed by management experts, or even, 'gurus' (Cappelli, 2008; Vinkenburg \& Pepermans, 2005) Recent advances in the field have mostly focused on global talent management, borrowing heavily from the literature on international human resource management (e.g. Collings, Scullion, \& Vaiman, 2011; Farndale, Scullion, \& Sparrow, 2010; Mellahi \& Collings, 2010; Schuler, Jackson, \& Tarique, 2011).

Although talent management is typically looked at through an HR lens (Lewis \& Heckman, 2006), other streams in the academic literature might also provide useful insights. The careers literature, in particular, covers a large volume of individual- and organizationallevel studies on careers taking place both inside and outside of organizational career management systems (e.g. Hall, 2002; Baruch \& Peiperl, 2000). Putting the careers literature alongside the talent management literature, some conflicting assumptions can be identified, however (see Table 1) - while most authors in the careers literature assume that the traditional organizational career is 'dead', the talent management literature advocates a renewed attention for continuity (e.g. succession planning, retention initiatives).

Based on an integrative review of both streams of the literature, we will argue that the more importance organizations attach to continuity - depending, at least in part, on their human capital composition in terms of the proportion of high-value, high-uniqueness employees - the more they will adhere to traditional models of career management. 
Organizational-level surveys administered to the HR directors of 306 companies located in Belgium provide the data for our study.

\section{Introduction}

Although many articles can be found in the literature testifying to the importance of talent management (e.g. Buckingham \& Vosburgh, 2001; Vance \& Vaiman, 2008), only a handful of them specify what they mean exactly by talent (Tansley, 2011). Interesting theoretical frameworks are found in the literature on giftedness (e.g. Gagné, 2004) and strengths (e.g. Biswas-Diener, Kashdan, \& Minhas, 2011), among others - however, as the current paper seeks to study talent management at the organizational rather than the individual level, we will build on Lepak and Snell's $(1999,2002)$ HR architecture model to formulate our hypotheses.

Lepak and Snell $(1999,2002)$ argue that the human capital of any given organization can be categorized along two dimensions - i.e., value and uniqueness. Value refers to the potential of the human capital at hand to contribute to its organization's core competence and enhance its competitive advantage. High-value human capital, hence, refers to assets that are pivotal to the organization's core business whereas low-value human capital generally refers to so-called 'peripheral' assets. Uniqueness refers to the extent to which the organization's human capital would be difficult to replace (high uniqueness) as opposed to being readily available in the labor market and easily copied by competitors (low uniqueness). Based on the conceptual dimensions of value and uniqueness, Lepak and Snell (1999) distinguish between four human capital quadrants each possessing different characteristics and carrying different HR implications. In the top right-hand corner of the model (quadrant I) we find human capital that is both valuable and unique. The recommended employment mode for employees falling into this quadrant is internal development, as highly unique skills are not easily 'bought' in the general labor market. The associated employment relationship, then, is 
organization-focused. Organization-focused exchange relationships encourage significant mutual investment both on the part of employers and employees to achieve long-term competitive advantage. In order to support or create such an employment relationship, organizations will likely rely on a continuity-based HR strategy that encourages employee involvement and optimizes their return on human capital investments. For example, they could sponsor career development and mentoring programs aimed specifically at developing organization-specific knowledge in their high-value, high-uniqueness employees (i.e. knowledge that is much more valuable within their specific context than to competitors) (Lepak \& Snell, 2002).

We propose that 'talent', at least from an organizational-strategic point of view, refers to the human capital in an organization that is both valuable and unique. The other three quadrants are much less likely to be selected for specific organizational career management programs. 'Internal partners' (quadrant II) are employees with skills that are valuable, but widely available in the labor market (i.e. high-value, low-uniqueness); 'contract workers' (quadrant III) are those with generic skills of limited strategic value, that can be acquired on an ad-hoc basis (i.e. low-value, low-uniqueness); finally, 'external partners' (quadrant IV) possess skills that are unique in some way, but not directly instrumental to the organization's competitive advantage (i.e. low-value, high-uniqueness) (Lepak \& Snell, 1999).

In an organization with a high proportion of high-value, high-uniqueness employees, continuity (i.e. the retention and succession of pivotal employees; Virany, Tushman \& Romanelli, 1992) is expected to be at the top of the agenda as high turnover, under these conditions, would pose a serious threat both in terms of qualitative and quantitative human capital shortages. 
Hypothesis 1. The higher the proportion of high-value, high-uniqueness employees and organization has, the more importance it will attach to continuity as a goal for its career management policies.

The recent careers literature, in contrast, states that more and more talented employees are acting like 'free agents' (Tulgan, 2001) and moreover, that this is a favorable evolution, liberating employees from the paternalistic practice of having an organization manage their careers (Van Buren, 2003). Continuity, in the careers literature, does not refer to the strategic purposes retention and succession of high-value, high-uniqueness employees can serve for organizations - rather, it refers to the notion of having an enduring vocational identity, whether within one employing organization or across employers (Simon \& Osipow, 1996).

With its focus on individual career outcomes (e.g. Sullivan \& Baruch, 2009), personal accountability for career management (see the literature on the 'protean' career, e.g. Hall, 2004), inter-organizational mobility (see the literature on the 'boundaryless' career, e.g. Verbruggen, 2012), and its decreased interest in formalized career management practices organized by organizations (De Vos, Dewettinck \& Buyens, 2009), the recent careers literature - at least at first glance - seems to be grounded in a number of assumptions that run diametrically opposite to those in the talent management literature (Table 1).

-- Insert Table 1 about here -

It is clear, however, that the career theory perspective departs almost solely from the individual career actor's point of view, in doing so largely ignoring the strategic function careers serve for organizations (Dries, Van Acker \& Verbruggen, 2012). In addition, an increasing number of scholars is expressing doubts about the claims made in the recent careers literature concerning the speed and inevitability of the 'death' of the traditional organizational career (e.g. Arnold \& Cohen, 2008; Guest \& Mackenzie Davey, 1996) - most empirical studies have demonstrated that both individuals and organizations still have a 
preference for organizational careers (Dries, 2011), leading some authors to label some of the assumptions made in the 'new' careers literature as rhetorical devices (e.g. Van Buren, 2003).

Although we are not denying that there have, in fact, been significant changes in the way careers are seen and enacted by individual employees, we posit that many organizations still adhere to traditional models of career management, and that the importance attached to continuity, which we argue depends on an organization's human capital composition (see Hypothesis 1), is one of the main determinants of an organization's career policies. More specifically, and building on our first hypothesis, we propose that when continuity is seen as a key deliverable of organizational career management policies, organizations will demonstrate an interest primarily in organizational outcomes, assume organizational accountability for career management, and have a clear preference for intra-organizational mobility and for highly formalized career management practices (Dries \& Pepermans, 2008). Hypothesis 2. The more importance an organization attaches to continuity as a goal for its career management policies, the more traditional its approach to careers will be, as demonstrated by (a) an interest in organizational career outcomes ('strategy') rather than individual ones ('psychology'); (b) the assumption of organizational accountability for career management ('paternalistic') rather than personal accountability ('protean'); (c) a preference for intra-organizational ('bounded') rather than inter-organizational ('boundaryless') mobility; and (d) a high number of formalized career management practices('focus on organizational career management') rather than a low number ('focus on career self-management').

Linking Hypothesis 1 and 2 together, we posit that the importance an organization attaches to continuity will act as a mediator in the relationship between that organization's human capital composition and its approach to career management. 
Hypothesis 3. The relationship between an organization's proportion of high-value, high-uniqueness employees and its approach to career management (i.e. less or more traditional) is mediated by the importance it attaches to continuity as a goal for its career management policies.

\section{Methods}

\section{Sample and Procedure}

The unit of analysis of the study was the organization. The study took place in Belgium in cooperation with a leading salary administration and HR consultancy firm, which provided information about the study and a link to the online survey in its newsletter, sent through e-mail to all its clients in March 2012. The final sample size was 306 organizations. Most respondents came from privately owned companies (86 percent), with a majority of small (30\% had between 50 and 99 employees) and medium-sized enterprises (38\% had between 100 and 249 employees). 15\% of the participating organizations employed between 250 and 499 employees and 17\% employed over 500 employees. The distribution in our data is representative of the proportion of companies from different sizes in Belgium (Ramsden \& Kiss-Haypál, 2000). In addition, participating organizations were distributed equally across the goods (33\%), services (36\%), and public sector (31\%). Most of them were local companies or international companies that have their headquarters in Belgium (76\%). The majority of respondents were HR managers or HR directors (60\%); 14\% were CEOs; 9\% were CFOs; and 1\% held yet another management position.

\section{The Belgian context}

It seems important to provide some background about Belgium so as to frame the generalizability of our findings within the cultural context in which the data were collected. Belgium reconciles different regional and cultural identities in a single federal structure. It has three communities - Dutch (which is the first language to $59 \%$ of the Belgian 
population), French (40\%), and German speaking (1\%) - and three regions: Flanders in the North where the official language is Dutch; Wallonia in the South where French is the official tongue (complemented by a very small German-speaking population) and Brussels, the capital, where French and Dutch share official language status. While some authors believe that Belgium is a Germanic country (similar in culture to Germany and Austria) (e.g. Schwartz, 1992), others have found that its culture is more similar to France and other LatinEuropean countries (e.g. Ronen, \& Shenkar, 1985).

Important events impacting on the current labor market situation in Belgium include the closure of a large number of heavy industry companies in the eighties, the growth of the state deficit in the eighties, and the rise of the unemployment rate in the nineties (Sels, Forrier, Bollens, \& Vandenbrande, 2005). In addition, as is the case in most developed economies around the world, Belgium is faced with a rapidly ageing labor force. Although younger workers in the European Union are, on average, achieving higher levels of education, demand for educated workers is not being met (Tucker, Kao, \& Verma, 2005). As for Belgium, demographic trends predict that the working-age population will stop increasing from the year 2015 onwards. After 2020, it will start shrinking, causing a decrease in potential employees (Sels, Van Woensel, \& Herremans, 2008). These demographic trends, together with a number of psychological contract trends (e.g. decreased employer-employee loyalty), are said to have caused a veritable 'war for talent', in that organizations are becoming increasingly worried about their capability to attract and engage the most talented people in the labor market (Michaels et al., 2001).

More generally, specific of the Belgian context is that Belgians score particularly high on uncertainty avoidance (preceded only by Japan; e.g. Spector, Cooper, \& Sparks, 2001), implying that continuity might be more important to Belgians than to people from other countries. Large-scale cross-cultural projects on work values have consistently shown that 
Belgians are generally risk-averse and resistant to change (e.g. Hofstede, 2001; Inglehart, 1997; Schwartz, 1992). Furthermore, studies into the career attitudes of Belgians, as a rule, conclude that the vast majority of Belgians is not in a boundaryless or protean career (Verbruggen, Sels, \& Forrier, 2007), that their self-perceived employability is sub-optimal (Sels, Stynen, De Winne, \& Gilbert, 2009), and that Belgians tend to prefer traditional psychological contracts where employee loyalty is offered in exchange for job security (Janssens, Sels, \& Van den Brande, 2003). Finally, Belgium is among the lowest-scoring European countries when it comes to career mobility as measured by number of career transitions and job and organizational tenure (Sels et al., 2005). Taken together, these findings do imply that Belgians tend to enact their careers within a quite 'traditional' context.

\section{Measures}

A set of measures was developed to correspond to the constructs in Table 1.

Value and uniqueness of human capital. Following the conceptualization by Lepak \& Snell (2002), value and uniqueness of human capital were assessed by asking respondents to indicate the proportion of their workforce that was (a) of high strategic value (value) and (b) difficult to find in the labor market (uniqueness), using a response scale ranging from $1=$ Less than $5 \%$ to $5=$ More than $75 \%$.

Importance attached to continuity. We asked respondents to indicate how important they considered continuity as a goal of career management in their organization using four items based on the work of Orpen (1994), e.g. "retaining our employees"; "anticipating or reacting to shortages in the external labor market". Respondents were instructed to indicate how important each of these goals of career management were using a five-point scale ranging from $1=$ Not at all important to $5=$ Very important. The Alpha for the scale was .64 .

We also included other possible goals of career management policies in the survey to control for other relevant differences between organizations in terms of strategy. We used 
Nishii, Lepak and Schneider's (2008) typology of five types of goals pursued by organizations in the execution of their HR strategy: (1) maximizing employee efficiency and productivity; (2) maximizing employee well-being; (3) controlling labor costs; (4) service quality enhancement; and (5) union compliance. Each goal was measured using one item scored on a five-point scale ranging from $1=$ Not at all important to $5=$ Very important, as suggested in Nishii et al. (2008).

Focus of career management. This variable was measured using a bidimensional scale with five anchors ranging from $1=$ Focus on the individual to $5=$ Focus on the organization with $3=$ An equal focus on both.

Accountability for career management. Based on the suggestions made by Briscoe, Hall \& Demuth (2006), accountability for career management was measured by asking respondents to indicate the extent to which employees in their organization were held responsible for managing their own career using a five-point scale ranging from $1=$ Fully responsible for managing their own career to $5=$ Not at all responsible for managing their own career.

Mobility preference. Mobility preference was measured by asking respondents to indicate the extent to which their organization aimed to offer its employees a long-term career perspective within the organization using a five-point scale ranging from $1=$ Not at all to $5=$ To a very great extent (based on Briscoe et al., 2006).

Number of formalized career management practices. Respondents were asked to indicate for a list of fifteen career management practices (see Appendix) based on the work of Baruch and Peiperl (2000), Eby, Allen, and Brinley (2005) and De Vos, Dewettinck, and Buyens (2008) the extent to which they were used in the organization. We recoded the data for this item into a dummy variable indicating whether the practice was used or not $(0=$ No; $1=$ Yes). We then created an index by summing the number of career management practices 
that were used by the organization. Sample items are "career planning workshops"; "internal announcement of vacancies"; "career conversations between supervisor and employee"; "self-assessment instruments" (see Appendix).

\section{Analyses}

To construct a typology of organizations in terms of their human capital composition, a hierarchical cluster analysis was performed in SPSS using our items on value and uniqueness. We used Ward's method, which is based on Euclidian distances, as it minimizes the variation within each cluster and looks for clusters of equal size. It is also considered the most robust method (Aldenderfer \& Blashfield, 1984). A four-cluster solution was ultimately withheld because of the clearly different pattern of the two human capital dimensions in this solution and the high number of respondents that could be allocated to a cluster (i.e. 289 out of 306). First, we looked for significant differences between the clusters using analysis of variance (ANOVA) with Bonferroni adjustment, as well as $\chi^{2}$ tests. By doing so, we could profile the clusters in terms of organizational characteristics and the six career management goals. Next, hierarchical regression analyses were used to examine each cluster's characteristics in terms of the focus of career management, accountability for career management, mobility preference, number of formalized career management practices, and the mediating role of importance attached to the different career management goals. The four clusters were transformed into dummy variables, using the low value, low uniqueness cluster as the reference category. We tested whether importance attached to continuity mediated the relationships between the human capital composition within an organization and the different outcomes in our model, following the steps proposed by Baron and Kenny (1986). First, we regressed career management goals on the cluster dummies with cluster 1 (low value, low uniqueness) as the reference category. Next, we regressed the outcomes on the clusters. Finally, for those outcomes that were significantly associated with career management goal 
and with clusters we assessed whether the relationship of the cluster with the outcome was still significant when importance attached to continuity was entered into the equation. In all regression analyses we controlled for company characteristics (i.e. size, sector) in order to improve the robustness of the tested relationships.

-- Insert Table 2 about here -

\section{Results}

Table 2 reports the descriptives and correlations between all study variables. Hierarchical clustering of the two human capital indicators revealed that a four-cluster solution was most appropriate (see Table 3). Cluster 1 contained 107 organizations with low scores on both human capital uniqueness and value. Cluster 2 was the smallest cluster, with 19 organizations reporting a high score on uniqueness and a low score on value. Respondents in cluster $3(n=84)$ had a low score on uniqueness and a high score on value. Finally, respondents in cluster $4(n=79)$ had a high score both on uniqueness and value.

These four clusters correspond to the four human capital quadrants proposed by Lepak and Snell (1999) in their HR architecture model.

-- Insert Table 3 about here -

Table 4 gives an overview of the profiles of the participating organizations across the four clusters. As shown, the four clusters did not differ significantly in terms of respondents' functions nor in terms of company characteristics. There were no significant differences in organization size, public versus private ownership, or local versus international ownership. Only for sector the $\chi^{2}$ test revealed significant differences. Cluster 1 and 2 contained relatively more organizations from the secondary sector (40.2 and 52.5 percent respectively), whilst this sector was relatively less represented in clusters 3 and 4 (22.6 and 26.6 respectively). Hence, sector was controlled for in the subsequent analyses. 
To assess the extent to which an organization's relative number of high-value, highuniqueness employees affects its career management goals, we first tested whether there were significant differences between the four clusters in terms of the six goals of career management using analysis of variance (ANOVA). As seen in Table 5, the four clusters did not differ significantly in terms of the importance attached to the five goals defined by Nishii et al. (2008). The only significant difference between the clusters related to the goal of continuity $(F=5.38, p<.01)$, thereby providing support for Hypothesis 1 . Given that we did not find significant differences between the clusters in terms of the five more general HR goals organizations might pursue through their career management, we did not include these in the subsequent regression analyses (see Figure 1).

-- Insert Table 5 about here -

The results of our regression analyses show that compared to organizations from cluster 1 (i.e. low value, low uniqueness), organizations from the three other clusters attached significantly more importance to the career management goal of preserving organizational continuity $(\beta=.31, p<.01$ for cluster $2, \beta=.19, p<.05$ for cluster $3, \beta=.35, p<.01$ for cluster 4), which is consistent with the ANOVA reported above, and in support of Hypothesis 1. Together, cluster membership and the control variables explained $11 \%$ of the variance in importance attached to continuity as a career management goal $\left(R^{2}=.11\right)$.

\section{-- Insert Figure 1 about here -}

In a next step, we assessed whether the goal of continuity related significantly to the indicators of a traditional approach to career management. Our results provide mixed evidence for Hypothesis 2. First, as regards focus on organizational career outcomes, in contrast to Hypothesis 2a the relationship with importance attached to continuity was found to be negative $(\beta=-.18, p<.01)$. Second, the relationship with organizational accountability for career management (Hypothesis $2 \mathrm{~b}$ ) proved non-significant $(\beta=-.11, p=\mathrm{ns})$. Third, our 
results revealed that importance attached to continuity was significantly and positively associated with a preference for intra-organizational mobility $(\beta=.36, p<.01)$, in support of Hypothesis 2c. Fourth, a positive association was found with number of formalized career management practices $(\beta=.22, p<.001)$, in support of Hypothesis $2 \mathrm{~d}$.

Next, we tested whether cluster membership was directly associated with the indicators of a traditional approach to career management. Compared to cluster 1 (i.e. low value, low uniqueness), organizations from cluster 4 (high-value, high-uniqueness) were significantly less focused on organizational outcomes $(\beta=-.16, p<.05)$, and scored significantly lower on organizational accountability for career management $(\beta=-.15, \mathrm{p}<$ .05). They scored significantly higher on preference for intra-organizational career mobility $(\beta=.14, p<.05)$, and had significantly more formalized career management practices in place $(\beta=.19, p<.01)$. Organizations from cluster 2 (low-value, high-uniqueness) reported significantly more formalized career management practices as compared to cluster 1 as well $(\beta=.17, p<.05)$.

Finally, to assess the mediating role of importance attached to continuity as a career management goal in the relationship between human capital composition and approach to career management (Hypothesis 3), for those outcomes for which a significant direct association with continuity and with human capital composition was found (i.e. focus of career management, mobility preference and number of formalized career management practices), we tested whether the relationship between the cluster and the outcome was still significant when entering continuity into the regression equation. In support of Hypothesis 3, our results show that continuity fully mediated all the above mentioned relationships between the clusters and outcomes (dashed lines in Figure 1). Taken together, of the four career management outcomes included in the study the dimension of mobility preference was most strongly affected by human capital composition and importance of continuity, as indicated by 
the proportion of explained variance $\left(R^{2}=.14\right)$, whilst for the other dimensions the proportion of variance explained was relatively low $\left(R^{2}=.05\right.$ for focus of career management, $R^{2}=.04$ for organizational accountability for career management, $R^{2}=.05$ for number of formalized career management practices.

\section{Discussion}

The current paper set out to gain empirical insight into how organizations' human capital composition (both in terms of uniqueness and strategic value) affects the way they design and implement their career management policies. Our basic assumption - based on a comparison of assumptions in the careers literature and the talent management literature was that the more importance organizations attach to continuity in light of their human capital composition, the more they will adopt a traditional approach to career management (i.e. strategic, paternalistic, bounded, and formalized - see Table 1).

Our study yielded mixed findings. In line with our expectations, the human capital composition of an organization (as measured by its relative number of high-value, highuniqueness employees) predicts the extent to which it attaches importance to continuity as a goal for its career management practices (also as expected, no differences were found for other potential career management goals). In addition, importance attached to continuity was found to mediate the relationship between human capital composition and approach to career management. Our results indicate that careers may be becoming more protean (as indicated by a focus on individual outcomes and individual accountability), as suggested in the careers literature (e.g. Briscoe et al., 2006), but not more boundaryless (as indicated by a clear preference for intra-organizational career mobility and formalized career management practices - typically considered 'bounded' and 'paternalistic' by contemporary careers scholars, Arnold \& Cohen, 2008). In fact, the variable that was most affected by the variables in our model was mobility preference, in the sense that more importance attached to 
continuity leads to an increased preference for intra-organizational (i.e. 'bounded') careers (see Figure 1).

Our findings also indicate that both threats of qualitative (value) and quantitative (uniqueness) human capital shortages are important determinants of importance attached to continuity and consequently, of an organization's approach to career management. As the correlation table shows, however, uniqueness (i.e. the proportion of an organization's workforce that is difficult to find in the labor market) in itself is only directly related to importance attached to continuity and not to the career management variables. We did find significant differences between organizations with many low value, low uniqueness employees and organizations with other human capital compositions (see Figure 1), thus demonstrating the added value of interpreting the two human capital dimensions conjointly. Specifically, our results imply that organizations with a high-value, high-uniqueness workforce are focused more than those with a low-value, low-uniqueness workforce on individual outcomes and accountability, whilst also providing opportunities for intraorganizational mobility and a high number of formalized career management practices.

Interpreting our findings the other way around we see that organizations with a lowvalue, low-uniqueness workforce (which, surprisingly, formed the largest cluster in our data) are mostly concerned with organizational outcomes, are less concerned with their employees' intra-organizational mobility, and offer fewer career management practices, whilst also holding individual employees less accountable for managing their own careers. Taken together, these findings imply that this type of organizations adopts a 'laissez-faire' approach to career management, in which neither career management nor continuity are an organizational priority.

\section{Limitations and Implications}


The study reported in this paper was cross-sectional and based on single-source reporting. Although, in the current study, the focus was not so much on individual attitudes but rather, on more or less objectively discernible features of organizational career management policies, common method variance might still have impacted on our results. Although it is difficult to exclude this type of bias entirely, longitudinal designs or multilevel designs might prove fruitful avenues for future research. Longitudinal designs would, for example, allow for within-company comparisons over time as their human capital composition (and type of shortage) changes. Multilevel studies might look at how different types of talent and career management strategies affect desired outcomes at the employee, team, and organizational level - such as productivity, competence, engagement, and intention to stay (Dries et al., 2012). Future studies might also include additional independent variables to operationalize organizations' human capital composition, as the $R^{2}$ effect sizes in our model were only small to moderate. This might also shed some light on the representativeness of our finding that many organizations report their own workforce to be both low in value and in uniqueness. The fact that we used only a single respondent per firm is also a limitation; further research is needed which also includes 'hard data' on career management practices, or that uses data collected from multiple respondents. Moreover, the use of single-item measures might limit the reliability of our findings. Another limitation is the small amount of variance accounted for by the study variables, which suggests that in addition to human capital composition and importance of continuity, other factors play a role in explaining an organization's career management approach. Possible factors to include in future research are, for instance, the age composition of the workforce or organizational factors such as strategy and structure.

Another suggestion for further research would be to examine organizations' differential approach to career management within their own workforce. The literature on 
workforce differentiation implies that different career management strategies can in fact exist within one and the same organization, depending on the target group or 'talent pool' concerned (e.g. Becker, Huselid \& Beatty, 2009). A final recommendation is that our findings should be cross-validated in countries with different cultural and labor market characteristics. As we discussed in the Methods section, Belgium is a rather 'traditional' context when it comes to career management and so findings might be different when data is collected in a different cultural and institutional setting.

Several authors have argued that careers researchers need to assume more responsibility for the social impact of their work, and scrutinize actual facts about current-day careers rather than develop new dogmas to replace the old ones (e.g. Arnold \& Cohen, 2008). The rhetoric about the 'death' of the organizational career is at risk of contributing to a 'winner-take-all' mentality in the labor market. Over the past few decades, a distinctly twotiered workforce has emerged, consisting of a small top tier of high value, high uniqueness employees whose bargaining position enables them to demand and receive fair treatment from employers; and a large second tier of employees whose skills are more 'replaceable' and who are far less assured of a bright career future (Van Buren, 2003) - a group that corresponds to the low-value, low-uniqueness cluster. There is a significant need and opportunity for more empirical research on contemporary careers in light of the human capital trends described in the talent management literature, if we want to be better able to discriminate conjectural from empirically supported ideas about careers in the current-day economy and inform policy makers of how talent management, organizational career management, and career self-management, respectively, can contribute to sustainable economic health at the societal level (Dries, 2011).

\section{Conclusion}


Although 'careers for life', admittedly, are a reality from a distant past (Sullivan \& Baruch, 2009), the organizational career is far from dead. In its enthusiasm to advocate selfdirectedness and personal agency (Arnold \& Cohen, 2008; Dries, 2011), the recent careers literature may have lost sight of the fact that careers still serve strategic purposes for organizations, especially now that 'war for talent' dynamics are becoming more pressing (Guest \& Mackenzie Davey, 1996; Michaels et al., 2001). Current economic conditions warrant a renaissance of research into organizational careers and career management practices, as the careers of many people are still enacted within the context of an organization (Hall \& Las Heras, 2009). It appears that the careers literature and the talent management literature are complementary, at least in some respects. The careers literature might take lessons from the talent management literature by acknowledging careers as an organizational concern that relates to its broader strategic human resource management practices (Dries et al., 2012). The talent management literature, on the other hand, might do well to acknowledge career actors' free agency - as Inkson (2008) pointed out, humans do not act as rationally and predictably as other resources. Therefore, studying talent management from a resource-based view perspective alone may not advisable. Insights from the careers literature - for example, from the work on subjective career success (e.g. Dries et al., 2008) and career orientations (e.g. Gerber, Wittekind, Grote, \& Staffelbach, 2009) - might help talent management researchers formulate recommendations on how organizations might achieve continuity as a result of their career management practices. 


\section{References}

Aldenderfer, M. S., \& Bashfield, R. K. (1984), Cluster Analysis. Quantitative Applications in the Social Sciences Series, 44. Newbury Park, CA: Sage.

Arnold, J. \& Cohen, L. (2008), 'The Psychology of Careers in Industrial and Organizational Settings: A Critical but Appreciative Analysis', In G.P. Hodgkinson \& J.K. Ford (Eds.), International review of industrial and organizational psychology (pp. 1-44). London, UK: Wiley.

Bacon, N. \& Hoque, K. (2005), 'HRM in the SME sector: Valuable Employees and Coercive Networks', The International Journal of Human Resource Management, 16(11), 1976-1999.

Baron, R. M., \& Kenny, D. A. (1986), 'The Moderator-Mediator Variable Distinction in Social Psychological Research: Conceptual, Strategic, and Statistical Considerations', Journal of Personality and Social Psychology, 51(6), 1173-1182.

Baruch, Y., \& Peiperl, M. (2000), 'Career Management Practices: An Empirical Survey and Implications', Human Resource Management, 39(4), 347.

Becker, B.E., Huselid, M.A. \& Beatty, R.W. (2009), The Differentiated Workforce: Transforming Talent into Strategic Impac,. Boston, MA: Harvard Business Press.

Biswas-Diener, R., Kashdan, T. B., \& Minhas, G. (2011), 'A Dynamic Approach to Psychological Strength Development and Intervention', The Journal of Positive Psychology, 6, $106-118$.

Boudreau, J.W. \& Ramstad, P. (2005), 'Talentship and the Evolution of Human Resource Management: From Professional Practices to Strategic Talent Decision Science', Human Resource Planning Journal, 28(2), 17-26.

Briscoe, J.P., Hall, D.T., \& DeMuth, R.L.F. (2006), 'Protean and Boundaryless Careers: An Empirical Exploration', Journal of Vocational Behavior, 69(1), 30-47. 
Buckingham, M. \& Vosburgh, R.M. (2001), 'The 21st Century Human Resources Function: It's the Talent, Stupid'!, Human Resource Planning, 24(4), 17-23.

Cappelli, P. (2008, March), 'Talent Management for the Twenty-First Century', Harvard Business Review, 1-8.

Collings, D.G. \& Mellahi, K. (2009), 'Strategic Talent Management: A Review and Research Agenda', Human Resource Management Review, 19(4), 304-313.

Collings, D.G., Scullion, H. \& Vaiman, V. (2011), 'European Perspectives on Talent Management', European Journal of International Management, 5(5), 453-462.

De Vos, A., \& Soens, N. (2008), 'Protean Attitude and Career Success: The Mediating Role of Self-Management, Journal of Vocational Behavior, 73, 449-456.

De Vos, A., Dewettinck, K., \& Buyens, D. (2008), 'To Move or Not to Move? The Relationship between Career Management and Preferred Career Moves', Employee Relations, 30(2), 156-175.

Dries, N. \& Pepermans, R. (2008), '’Real' High Potential Careers: An Empirical Study into the Perspectives of Organizations and High Potentials', Personnel Review, 37(1), 85-108.

Dries, N. (2011), 'The Meaning of Career Success: Avoiding Reification through a Closer Inspection of Historical, Cultural and Ideological Contexts', Career Development International, 16(4), 364-384.

Dries, N., Van Acker, F., \& Verbruggen, M. (2012), 'How 'Boundaryless' are the Careers of High Potentials, Key Experts and Average Performers?', Journal of Vocational Behavior, corrected proof, early online.

Dries, N., Van Esbroeck, R., van Vianen, A.E.M., De Cooman, R. \& Pepermans, R. (2012), 'Career Adapt-Abilities Scale-Belgium Form: Psychometric Characteristics and Construct Validity', Journal of Vocational Behavior, 80(3), 674-679. 
Eby, L. T., Allen, T. D., \& Brinley, A. (2005), 'A Cross-Level Investigation of the Relationship between Career Management Practices and Career-Related Attitudes', Group \& Organization Management, 30(6), 565-596.

Farndale, E., Scullion, H., \& Sparrow, P. (2010), 'The Role of the Corporate HR Function in Global Talent Management', Journal of World Business, 45(2), 161-168.

Gagné, F. (2004), ‘Transforming Gifts into Talents: The DMGT as a Developmental Theory’, High Ability Studies, 15, 119 - 147.

Gerber, M., Wittekind, A., Grote, G., \& Staffelbach, B. (2009), 'Exploring Types of Career Orientation: A Latent Class Analysis Approach', Journal of Vocational Behavior, 75(3), 303-318.

Guest, D. \& Mackenzie Davey, K. (1996, February), 'Don’t Write Off the Traditional Career', People Management, 22-25.

Hall, D. T., \& Las Heras, M. (2009), 'Long live the Organisational Career', In A. Collin, \& W. Patton (Eds.), Vocational Psychological and Organisational Perspectives on Career: Towards a Multidisciplinary Dialogue (pp. 181-196). Rotterdam, The Netherlands: Sense Publishers.

Hall, D.T. (2002), Careers In and Out of Organizations. Thousand Oaks, CA: Sage. Hiltrop, J. M. (1999), 'The Quest for the Best: Human Resource Practices to Attract and Retain Talent', European Management Journal, 17 (4), 422-430.

Hofstede, G. (2001), Culture's Consequences: Comparing Values, Behaviors, Institutions, and Organizations across Nations. Thousand Oaks, CA: Sage Publications.

Inglehart, R. (1997), Modernization and Postmodernization: Cultural, Economic, and Political Change in 43 Societies. Princeton, N.J.: Princeton University Press. Janssens, M., Sels, L., \& Van den Brande, I. (2003), 'Multiple Types of Psychological Contracts: A Six-Cluster Solution', Human Relations, 56 (11), 1349-1378. 
Lepak, D. P., \& Snell, S. A. (1999), 'The Human Resource Architecture: Toward a Theory of Human Capital Allocation and Development', The Academy of Management Review, 24(1), 31-48.

Lepak, D. P., \& Snell, S. A. (2002), 'Examining the Human Resource Architecture: The Relationships among Human Capital, Employment, and Human Resource Configurations', Journal of Management, 28(4), 517-543

Lewis, R.E. \& Heckman, R.J. (2006), 'Talent Management: A Critical Review', Human Resources Management Review, 16(2), 139-154.

Mellahi, K., \& Collings, D. G. (2010), 'The Barriers to Effective Global Talent Management: The Example of Corporate Élites In MNEs', Journal of World Business, 45(2), 143 149

Michaels, E., Handfield-Jones, H., \& Axelrod, B. (2001), The War for Talent. Boston, MA: Harvard Business School Press.

Nishii, L. H., Lepak, D. P., \& Schneider, B. (2008), 'Employee Attributions of the "Why” Of HR Practices: Their Effects on Employee Attitudes and Behaviors, and Customer Satisfaction', Personnel Psychology, 61(3), 503-545.

Orpen, C. (1994), 'The Effects of Organizational and Individual Career Management on Career Success', International Journal of Manpower, 15(1), 27-37.

Ramsden, J. J. \& Kiss-Haypál, G. (2000), 'Company Size Distribution in Different Countries', Physica A, 277: 220-227.

Ronen, S. \& Shenkar, O. (1985), 'Clustering Countries on Attitudinal Dimensions: A Review and Synthesis', Academy of Management Review, 10, 435-454.

Schuler, R.S., Jackson, S.E., \& Tarique, I. (2011), 'Global Talent Management and Global Talent Challenges: Strategic Opportunities for IHRM', Journal of World Business, 46(4), 506-516. 
Schwartz, S.H. (1992), 'Universals in the Content and Structure of Values: Theoretical Advances and Empirical Tests in 20 Countries', In M. Zanna (Ed.), Advances in Experimental Social Psychology (Vol. 25, pp. 1-65). Orlando, FL: Academic Press.

Sels, L., Forrier, A., Bollens, J., \& Vandenbrande, T. (2005), 'What we (Don't) Know about Careers in Flanders. Taking stock', In Vrancken J., Jans M., van der Hallen P. (Eds.), Labour Market Research and Policy Making in Flanders. Conference book (pp. 97124). Antwerpen, Belgium: Garant.

Sels, L., Stynen, D., De Winne, S., \& Gilbert, C. (2009), De Gevolgen Van Arbeidsmobiliteit: Een Overzicht op Macro-, Meso- en Microniveau [The Consequences of Labor Mobility: An Analysis at the Macro, Meso, and Micro Level], WSE Report n ${ }^{\circ}$ 042009.

Sels L., Van Woensel A. \& Herremans, W. (2008), 'Over Rode, Oranje en Groene Lichten in het Eindeloopbaanbeleid' [About Red, Orange and Green Lights in the 'Career Ending Policies'], Over.Werk. Tijdschrift van het Steunpunt WSE, 1, 8 -33.

Simon, J. \& Osipow, S. H. (1996), 'Continuity of Career: The Vocational Script in Counseling Older Workers', The Career Development Quarterly, 45(2), 152-162.

Spector, P.E., Cooper, C.L., \& Sparks, K. (2001), 'An International Study of the Psychometric Properties of the Hofstede Values Survey Module 1994: A Comparison of Individual and Country/Province Level Results', Applied Psychology: An International Review, 50 (2), 269-281.

Sullivan, S.E. \& Baruch, Y. (2009), 'Advances in Career Theory and Research: A Critical Review and Agenda for Future Exploration', Journal of Management, 35(6), 1542 1571.

Tansley, C. (2011), 'What Do we Mean by the Term “Talent” in Talent Management?', Industrial and Commercial Training, 43(5), 266-274. 
Tucker, E., Kao, T. \& Verma, N. (2005, July/August), 'Next-Generation Talent Management: Insights on How Workforce Trends are Changing the Face of Talent Management', Business Credit, 107, 20-27.

Tulgan, B. (2001), ,Winning the Talent Wars', Employment Relations Today, 23(1-2), 37-51. Van Buren, H.J. III (2003), Boundaryless Careers and Employability Obligations, Business Ethics Quarterly, 13(2), 131-149.

Vance, C.M. \& Vaiman, V. (2008), 'Smart Talent Management: On the Powerful Amalgamation of Talent Management and Knowledge Management', In V. Vaiman \& C.M. Vance (Eds.). Smart Talent Management: Building Knowledge Assets for Competitive Advantage (pp. 1-18). Cheltenham, UK: Edward Elgar Publishing. Verbruggen, M. (2012), 'Psychological Mobility and Career Success in the 'New' Career Climate', Journal of Vocational Behavior, corrected proof, early online.

Verbruggen, M., Sels, L., \& Forrier, A. (2007), 'Unraveling the Relationship between Organizational Career Management and the Need for External Career Counselling,, Journal of Vocational Behavior, 71 (1), 69-83.

Vinkenburg, C. \& Pepermans, R. (2005), 'Top Potentials in Organisaties - Een Inleiding' [Top Potentials in Organizations - An Introduction], In C. Vinkenburg \& R. Pepermans (Eds.), Top Potentials in Organisaties: Identificeren, Ontwikkelen, Binden [Top Potentials in Organizations: Identification, Development, Engagement] (pp. 316). Assen, The Netherlands: van Gorcum.

Virany, B., Tushman, M.L. \&Romanelli, E. (1992), 'Executive Succession and Organization Outcomes in Turbulent Environments: An Organization Learning Approach', Organization Science, 2, 72-91. 
Table 1

The Careers versus the Talent Management Literature: Conflicting Assumptions

Credo "Build a career in which I can use and

1. Importance attached to continuity

2. Focus of career management

3. Accountability for career management Self (Protean)

4. Mobility preference

5. Number of formalized CM practices

Notes. $\mathrm{CM}=$ Career management; CSM

\section{Careers literature} develop my talents in view of my personal career drivers and goals"

Low

Individual (Psychology)

Inter-organizational (Boundaryless)

\section{Talent management literature}

'Detect, develop, and deploy employees' talents in order to obtain superior performance at the individual, group, and organizational level"

High

Organizational (Strategy)

Organization (Paternalistic)

Intra-organizational (Bounded)

Low (Focus on CSM)

High (Focus on OCM) 
Table 2

Means, Standard Deviations, and Correlations

\begin{tabular}{|c|c|c|c|c|c|c|c|c|c|c|c|c|c|c|}
\hline & $M$ & $s d$ & 1 & 2 & 3 & 4 & 5 & 6 & 7 & 8 & 9 & 10 & 11 & 12 \\
\hline 1. Value of human capital & 3.40 & 1.11 & -- & & & & & & & & & & & \\
\hline 2. Uniqueness of human capital & 2.82 & 1.19 & $.25^{* *}$ & -- & & & & & & & & & & \\
\hline 3. Importance attached to continuity & 4.04 & .49 & $.32^{* *}$ & $.21^{*}$ & -- & & & & & & & & & \\
\hline 4. Importance attached to efficiency & 4.28 & .65 & .00 & .05 & $.19^{*}$ & -- & & & & & & & & \\
\hline 6. Importance attached to cost control & 4.18 & .83 & .02 &,- 12 & .13 & $.17^{*}$ & .08 & -- & & & & & & \\
\hline 7. Importance attached to quality & 4.35 & .53 & .14 & .04 & $.19^{*}$ & $.17^{*}$ & $.28^{* *}$ & .02 & -- & & & & & \\
\hline 8. Importance attached to compliance & 3.80 & 1.08 & .10 & -.08 & -.01 & .02 & $.18^{*}$ & $.44^{* *}$ & .14 & -- & & & & \\
\hline 9. Focus on organizational outcomes & 3.68 & .84 & $-.13^{*}$ & -.06 & $-.18^{*}$ & -.00 & $-.16^{*}$ & .04 & -.07 & -.04 & -- & & & \\
\hline 11. Preference for intra-organizational mobility & 3.37 & .98 & $.13^{*}$ & .08 & $.36^{* *}$ & .03 & -.03 & -.13 & .06 & $-.17^{*}$ & -.10 & $-.13^{*}$ & -- & \\
\hline 12. Number of formalized career management practices & 2.15 & 2.07 & $.24^{* *}$ & .11 & $.22^{* *}$ & .16 & .13 & -.07 & $.20^{*}$ & .05 & $-.22^{* *}$ & $-.24^{* *}$ & .11 & -- \\
\hline
\end{tabular}

Notes $* p<05 ; * * p<01$ 
Table 3

Four-Cluster Solution: Means and Standard Deviations on Human Capital Dimensions

\begin{tabular}{lccccc}
\hline & $\begin{array}{c}\text { Cluster 1 } \\
n=107\end{array}$ & $\begin{array}{c}\text { Cluster 2 } \\
n=19\end{array}$ & $\begin{array}{c}\text { Cluster 3 } \\
n=84\end{array}$ & $\begin{array}{c}\text { Cluster } 4 \\
n=79\end{array}$ & $\begin{array}{c}\text { Total } \\
n=289\end{array}$ \\
\hline Value & $2.42(.66)$ & $2.00(.47)$ & $4.27(.45)$ & $4.15(.70)$ & $3.40^{*}(1.11)$ \\
& & & & $C_{4}>C_{1}, C_{2}$ \\
& & & & $C_{3}>C_{1}$ \\
Uniqueness & $2.06(.66)$ & $4.26(.45)$ & $2.14(.75)$ & $4.24(.43)$ & $2.82^{*}(1.19)$ \\
& & & & & $C_{2}, C_{4}>C_{1}, C_{3}$ \\
\hline
\end{tabular}

Notes. ${ }^{*} p<.001 ; C_{1,2,3,4}=$ cluster $1,2,3,4$. 
Table 4

Profiles of the Organizations and Respondents in the Four Clusters

\begin{tabular}{|c|c|c|c|c|c|}
\hline Characteristics & Cluster 1 & Cluster 2 & Cluster 3 & Cluster 4 & Total \\
\hline \multicolumn{6}{|l|}{ Size (percent) } \\
\hline $50-99$ & 28 & 31.6 & 29.8 & 32.9 & 30.1 \\
\hline $100-249$ & 43 & 42.1 & 32.1 & 35.4 & 37.7 \\
\hline $250-499$ & 14 & 10.5 & 20.2 & 12.7 & 15.2 \\
\hline$\geq 500$ & 14.5 & 15.8 & 17.8 & 19 & 17 \\
\hline \multicolumn{6}{|l|}{ Sector (percent) } \\
\hline Goods & 40.2 & 52.6 & 22.6 & 26.6 & $32.3^{*}$ \\
\hline Services & 35.5 & 15.8 & 39.3 & 38 & $36^{*}$ \\
\hline Public & 23.4 & 31.6 & 36.9 & 30.4 & $29.8^{*}$ \\
\hline \multicolumn{6}{|l|}{ Public vs. private (percent) } \\
\hline Public & 7.5 & 10.5 & 14.3 & 8.9 & 10 \\
\hline Private & 90.7 & 84.2 & 83.3 & 88.6 & 85.5 \\
\hline \multicolumn{6}{|c|}{ Local vs. international (percent) } \\
\hline Local & 74.8 & 73.7 & 79.8 & 74.7 & 76.1 \\
\hline International & 25.2 & 26.3 & 19 & 25.3 & 23.5 \\
\hline \multicolumn{6}{|l|}{ Respondent (percent) } \\
\hline HR manager/HR director & 60.8 & 63.2 & 60.7 & 58.3 & 60.2 \\
\hline $\mathrm{CEO}$ & 9.3 & 10.5 & 16.7 & 19 & 14.2 \\
\hline $\mathrm{CFO}$ & 14 & 10.6 & 7.2 & 3.8 & 9 \\
\hline
\end{tabular}

Notes. ${ }^{*} p<.05$; Cluster $1=$ low-value, low-uniqueness; Cluster 2 = low-value, high-uniqueness; Cluster 3 = high-value, low-uniqueness; Cluster $4=$ high-value, high-uniqueness. 
Table 5

Differences in Career Management Goals between the Four Clusters

\begin{tabular}{lccccc}
\hline & $\begin{array}{c}\text { Cluster } 1 \\
n=107\end{array}$ & $\begin{array}{c}\text { Cluster } 2 \\
n=19\end{array}$ & $\begin{array}{c}\text { Cluster } 3 \\
n=84\end{array}$ & $\begin{array}{c}\text { Cluster } 4 \\
n=79\end{array}$ & $\begin{array}{c}\text { Total } \\
n=289\end{array}$ \\
\hline Continuity & $3.79(.50)$ & $4.21(.38)$ & $4.15(.38)$ & $4.15(.38)$ & $\begin{array}{c}4.04(.49)^{*} \\
C_{3}, C_{4}>C_{1}\end{array}$ \\
$\begin{array}{l}\text { Maximizing } \\
\text { efficiency }\end{array}$ & $4.23(.61)$ & $4.57(.34)$ & $4.29(.70)$ & $4.27(.66)$ & $4.28(.65)$ \\
$\begin{array}{l}\text { Maximizing } \\
\text { well-being }\end{array}$ & $3.96(.64)$ & $4.00(.58)$ & $4.07(.65)$ & $4.17(.51)$ & $4.07(.60)$ \\
$\begin{array}{l}\text { Controlling } \\
\text { costs }\end{array}$ & $4.09(.84)$ & $4.57(.79)$ & $4.40(.75)$ & $4.02(.85)$ & $4.18(.83)$ \\
$\begin{array}{l}\text { Quality } \\
\text { enhancement }\end{array}$ & $4.23(.53)$ & $4.57(.54)$ & $4.47(.55)$ & $4.33(.51)$ & $4.35(.53)$ \\
$\begin{array}{l}\text { Union } \\
\text { compliance }\end{array}$ & $3.72(1.01)$ & $3.43(1.77)$ & $3.98(1.18)$ & $3.75(1.03)$ & $3.8(1.08)$ \\
\hline
\end{tabular}

Notes. ${ }^{*} p<.05 ; C_{1,2,3,4}=$ cluster 1, 2, 3, 4; Cluster $1=$ low-value, low-uniqueness; Cluster $2=$ low-value, high-uniqueness; Cluster $3=$ highvalue, low-uniqueness; Cluster $4=$ high-value, high-uniqueness. 


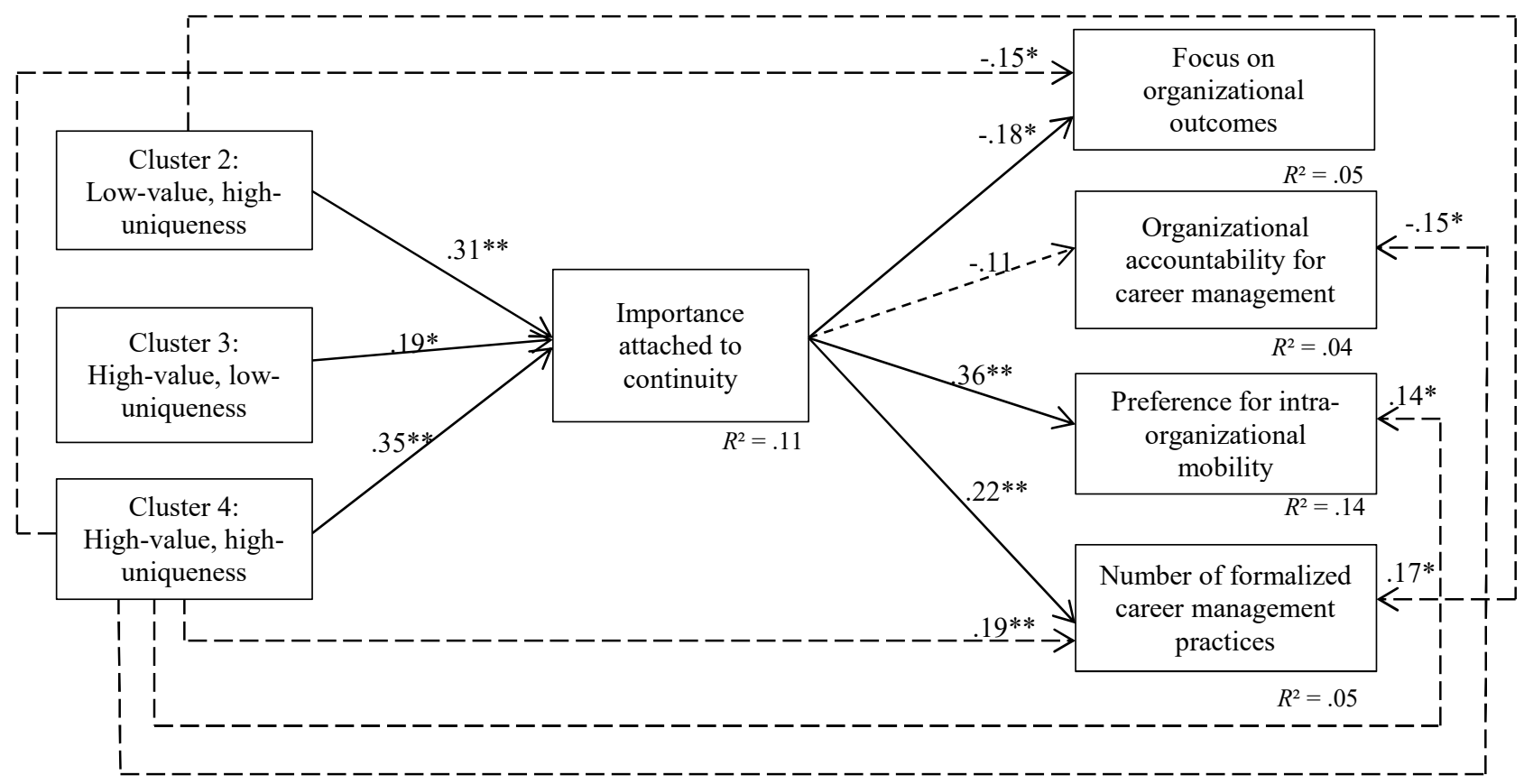

Notes. ${ }^{*} p<.05 ; * *<.01$; Reference category = cluster 1 (low value, low uniqueness); Dashed lines represent significant effects that are fully mediated by continuity.

Figure 1. Results of the Regression Analyses. 
Appendix.

List of formalized career management practices.

1. Career planning workshops

2. Formal mentoring programs

3. Succession planning

4. Coaching

5. Prescribed career paths

6. Internal announcement of vacancies

7. Individual career counseling by internal or external career counselors

8. Training outside current function

9. Talent reviews

10. Job rotation

11. Development centers to assess potential

12. Self-assessment instruments

13. Personal development plan

14. Information about career development

15. Formal career conversations between supervisor and employee

(Based on the work of Baruch \& Peiperl, 2000; Eby, Allen \& Brinley, 2005; De Vos, Dewettinck \& Buyens, 2008) 